\title{
REDUCTION OF UNWANTED ZINC CONTENT IN METALLURGICAL WASTES AND DESIGN OF ROTARY KILN
}

\author{
${ }^{1}$ Vladislav KURKA, ${ }^{1}$ Jaroslav PINDOR, ${ }^{2}$ Jozef VLČEK, ${ }^{1}$ Petr JONŠTA \\ 'MATERIÁLOVÝ A METALURGICKÝ VÝZKUM s.r.o., Ostrava, Czech Republic, EU, \\ vladislav.kurka@mmvyzkum.cz \\ ${ }^{2}$ VSB - Technical University Ostrava, Faculty of Materials Science and Technology, Ostrava, \\ Czech Republic, EU, josef.vlcek@vsb.cz
}

https://doi.org/10.37904/metal.2019.677

\begin{abstract}
Currently, there is increasing pressure to reduce waste generation and to use it as a secondary raw material. In the framework of this work, there are presented beginning parts of the project plan called "Research of processing of metallurgical waste, materials and by-products from metallurgical and related operations number CZ.02.1.01/0.0/0.0/17_049/0008426“. The authors deal with the problems including the basic description of processes leading to the reduction of non-ferrous metals in metallurgical wastes. Including a rough draft of the prepared laboratory, which will be used for metallurgical waste treatment, especially in reducing the proportion of non-ferrous metals.
\end{abstract}

Keywords: Metallurgy, waste, slag, lead, zinc, thermal, treatment

\section{INTRODUCTION}

Apart from slugs, metallurgical companies also generate a broad range of other by-products, wastes or materials which are not the primary target of metallurgical production. In response to the implementation of the latest ecologisation measures, there is greater efficiency in the capture of solid particles, which are formed during purification of the gas in metallurgy and related production processes. The captured solid particles are a waste product in the metallurgical industry, whose further processing and use is one of the research tasks of this project.

Research project in methods for handling wastes, materials and by-products of metallurgical and related plants, CZ.02.1.01/0.0/0.0/17_049/0008426 is in principle divided into two research tasks. The first task concerns the issue of metallurgical wastes mainly from slags and the second research task concerns the issue of solid metallurgical wastes, sludge and non-ferrous metals in these wastes. In this work, we shall deal with only the second research task.

The main objective of the presented work is research into the efficient disposal of solid wastes, by-products and materials of metallurgical processes and related operations with the focus on their potential greatest secondary use and current reduction of ecological burdens. This mainly concerns research into the potential of their use for the preparation of new material products with higher value added than mere recycling of these waste materials.

The solution procedure or partial objectives are as follows:

- The characterization and catalogization of the products of dry and wet cleaning of waste gases and other solid wastes from the metallurgical industry and related technologies according to the criteria of the potential follow-up material use.

- The definition of the conditions for processing of the monitored wastes with the objective to exploit their potential material use.

- Choice of the methods required for adaptation of the parameters of the monitored wastes with the objective to separate the materially exploitable and unexploitable components. 
- $\quad$ Stabilisation of the materially unexploitable wastes in terms of technical or economic feasibility with the emphasis on the suppression of negative environmental impacts.

- $\quad$ Experimental laboratory verification of the practical applicability of the adopted solutions.

The above-stated partial objectives are closely related to the research activities within the scope of the entire project and are related to the equipment of the experimental laboratory focused mainly on research into the processes of removal of non-ferrous metals from solid metallurgical wastes.

\section{ROTARY KILN}

For research into the processing of metallurgical waste, the rotary gas-fired kiln principle shall be used. These kilns are mainly used for drying, sintering, roasting, production of metals, etc. An example of the rotary kiln manufactured by Feeco international [1] is presented in Figure 1. The rotary kiln is only one component of a large whole, which is far larger than the kiln itself because it includes the preparation of the charge, equipment for gas injection, cleaning of flue gases, processing of the product from the kiln, see Figure 2 [2]. Industrial rotary kilns are natural gas fired. According to

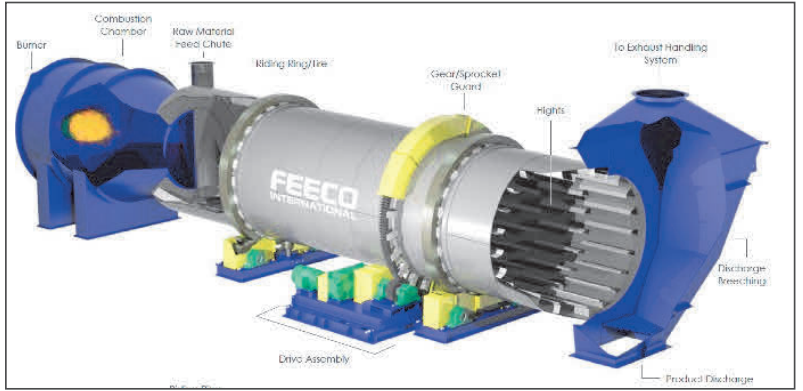

Figure 1 Rotary kiln manufactured by Feeco International [1] the gas contact with the heated material, we divide rotary kilns into two basic types. The first type is the indirect kiln, where the gas and its flue gases are not in contact with the heated material, see Figure 3. The second type is the direct kiln, where the gas and its flue gases are in contact with the heated material, see Figure 4. The rotary kiln lining is made of refractory material, be it is bricked or cast, see Figure 5 .

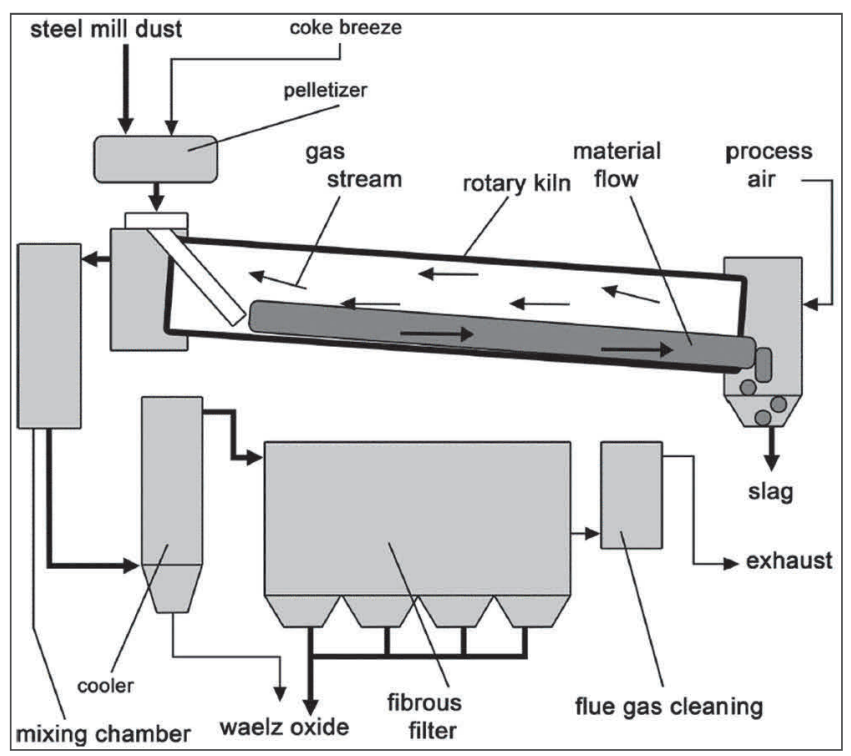

Figure 2 Waelz process route [2]

During direct gas heating of the material, the heat is transmitted directly from the flame to the material. The temperature of the flame and its flue gases can rise up to $3,500{ }^{\circ} \mathrm{C}$. The material is further heated by radiation from the kiln itself and conduction of heat from the refractory material of the kiln, see Figure 6 . When using indirect heating of the material, the heat is transmitted to the material only by radiation from the inner shell of the kiln and the conduction of heat from the inner parts of the refractory lining of the kiln. 


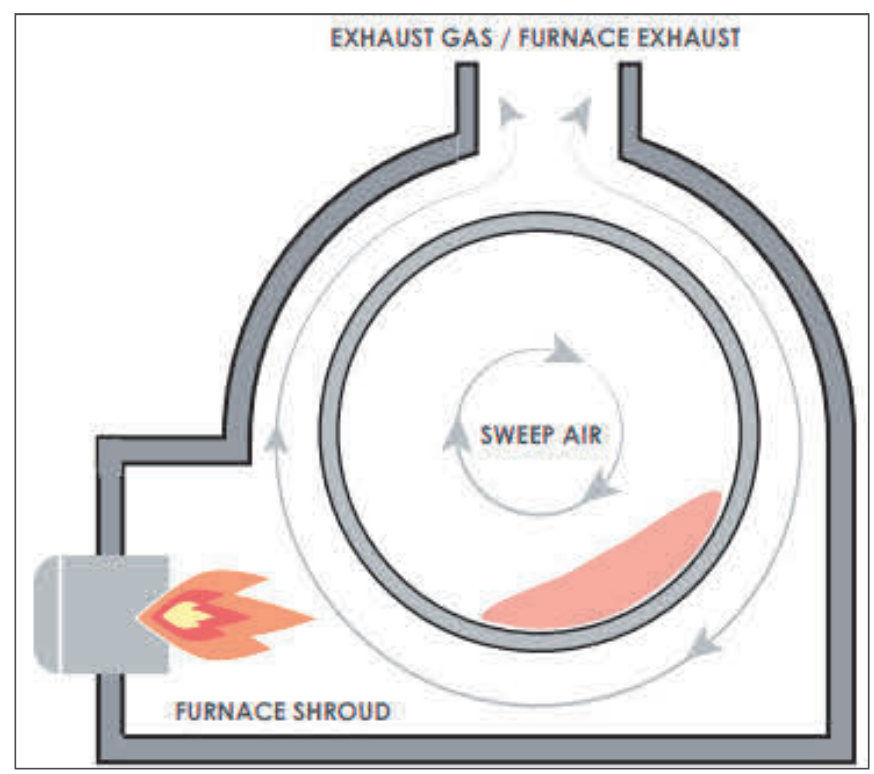

Figure 3 Rotary direct-fired kiln with indirect heating [1]

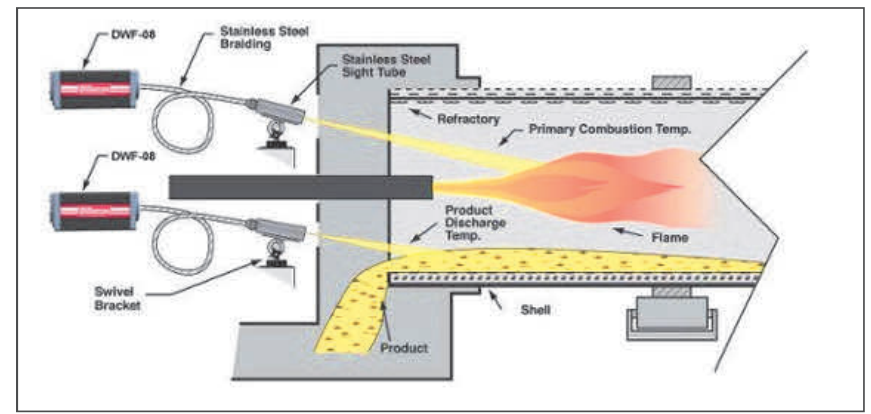

Figure 4 Rotary direct-fired kiln with direct heating [3]

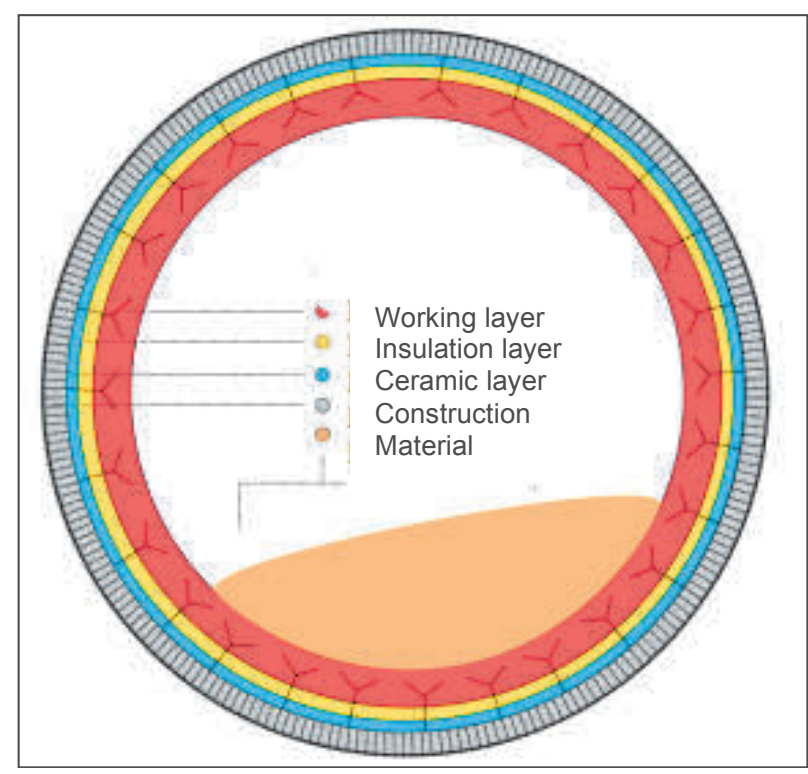

Figure 5 Cast lining [1]

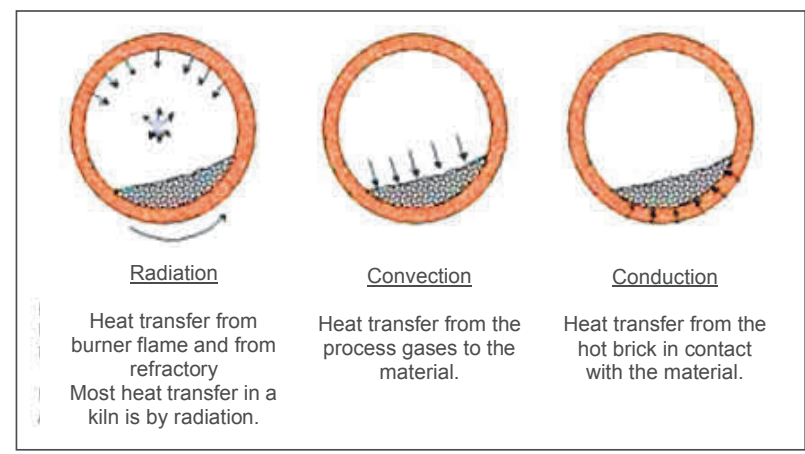

Figure 6 Transfer of heat to the material in the kiln [4]

\section{REMOVAL OF ZN}

The research into waste raw materials processing within the project shall focus on the removal of $\mathrm{Zn}$ from metallurgical wastes, mainly dedusting. $\mathrm{Zn}$ from the dedusting is removed at high temperature; the method for removal of $\mathrm{Zn}$ using $\mathrm{CO}$ and then using $\mathrm{Cl}$ is described in this paper.

In the first case, the method for removal of $\mathrm{Zn}$ using $\mathrm{CO}$ and $\mathrm{O}_{2}$ is described; the primary reaction in the rotary kiln is presented in Figure 7. Thanks to its low boiling temperature, $\mathrm{Zn}$ evaporates at a temperature of $907^{\circ} \mathrm{C}$. The author [2] describes the primary reaction of $\mathrm{Zn}$ in gaseous form with oxygen using the equations (1), (2) and (3) and in the charge using the equations (4) to (9) [2].

The author [2] also mentions the removal of $\mathrm{Zn}$ from molten slag in a lead production kiln with excessive air and coal or coke. The reactions take place in the kiln according to Figure 8 at a temperature of 1,300 to $1,500{ }^{\circ} \mathrm{C}$. During the removal of $\mathrm{Zn}$ in rotary kilns, the flame heats the air mass in the kiln up to a temperature of $2,000{ }^{\circ} \mathrm{C}$ and the material reaches a temperature of $1,500{ }^{\circ} \mathrm{C}$, see Figure 9 according to [5].

Reaction in the gas phase (oxidizing):

$\{\mathrm{Zn}\}+1 / 2\{\mathrm{O} 2\} \rightarrow \mathrm{ZnO}$ 
$\{\mathrm{CO}\}+1 / 2\{\mathrm{O} 2\} \rightarrow\{\mathrm{CO} 2\}$

$\{\mathrm{Zn}\}+\{\mathrm{CO}\}+\{\mathrm{O} 2\} \rightarrow \mathrm{ZnO}+\{\mathrm{CO} 2\}$

Reaction in the charge (reducing):

$(\mathrm{ZnO})+\{\mathrm{CO}\} \rightarrow\{\mathrm{Zn}\}+\{\mathrm{CO} 2\}$

$\{\mathrm{CO} 2\}+\mathrm{C} \rightarrow 2\{\mathrm{CO}\}$

$(\mathrm{ZnO})+\mathrm{C} \rightarrow\{\mathrm{Zn}\}+\{\mathrm{CO}\}$

$(\mathrm{FeO})+\{\mathrm{CO}\} \rightarrow \mathrm{Fe}+\{\mathrm{CO} 2\}$

$\{\mathrm{CO} 2\}+\mathrm{C} \rightarrow 2\{\mathrm{CO}\}$

$(\mathrm{FeO})+\mathrm{C} \rightarrow \mathrm{Fe}+\{\mathrm{CO}\}$

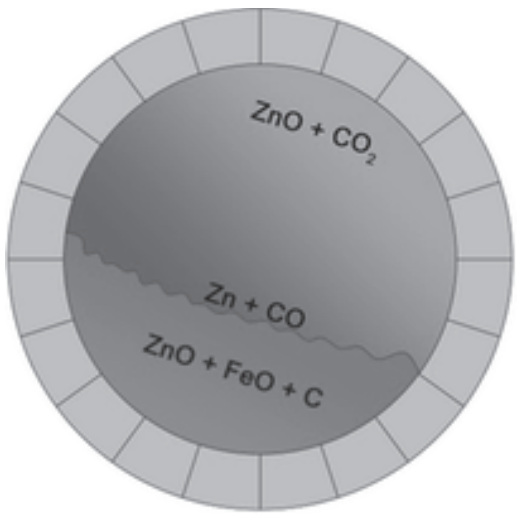

Figure 7 Main reactions in the Waelz kiln, removal of $\mathrm{Zn}$ [2]

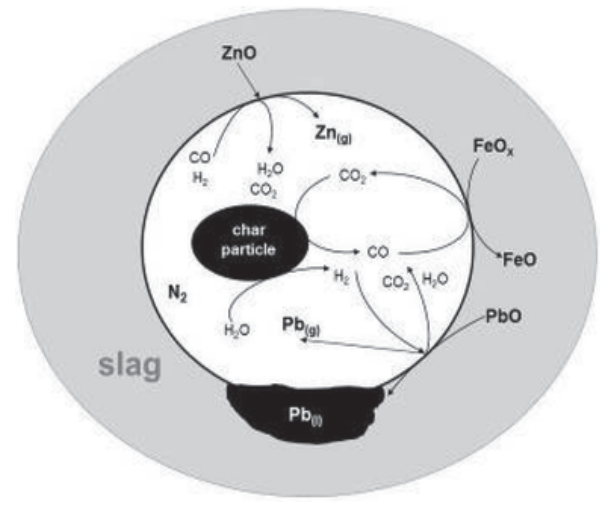

Figure 8 Reaction system occurring in the slag fuming process [2]

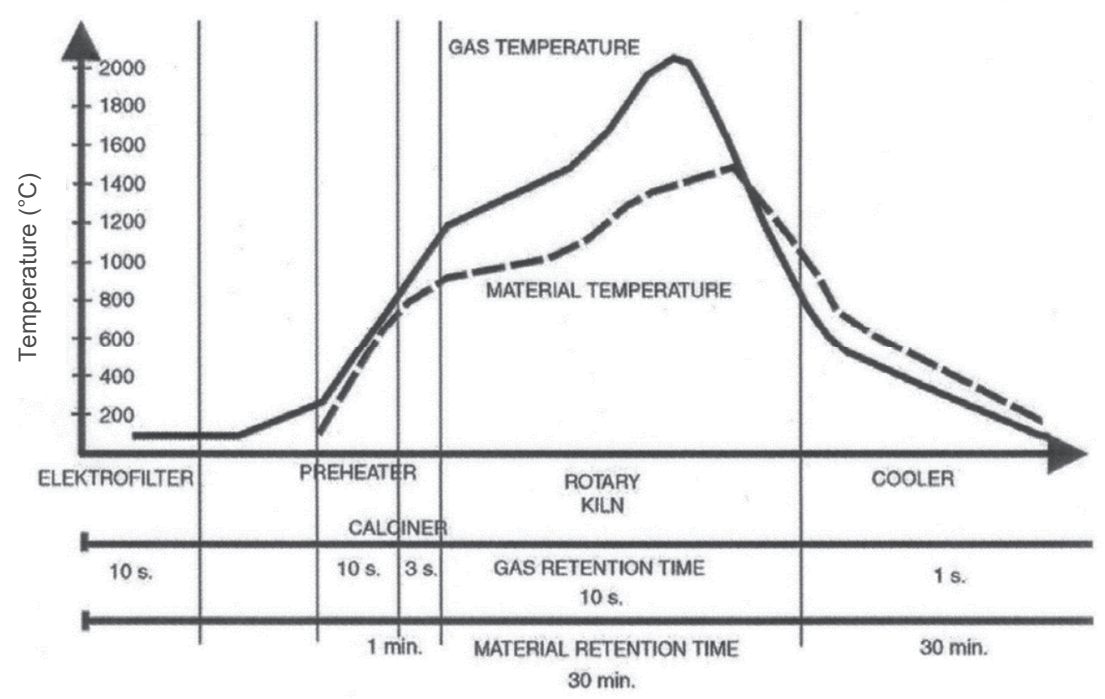

Figure 9 Diagram showing entrance points of AFR in the cement plant as well as temperature profile and retention time of gas and solids [5] 
The second method for removal of $\mathrm{Zn}$ is use of $\mathrm{Cl}$ at high temperature. When removing $\mathrm{Zn}$, the author [6] recommends the use of chlorides simultaneously with high temperature. Where $\mathrm{Zn}$ can be removed completely in the temperature range 650 to $900{ }^{\circ} \mathrm{C}$ with the addition of $10 \%$ weight of $\mathrm{Cl}$, best at a temperature of $1,000{ }^{\circ} \mathrm{C}$. The $\mathrm{Zn}$ is extracted in the form of $\mathrm{ZnCl}_{2}$. The author further refers to the negative impact of $\mathrm{H}_{2} \mathrm{O}$ in the flue gases during removal of $\mathrm{Zn}$, and on the contrary to the positive impact of $\mathrm{Si}$ in the input raw material. The average composition of the atmosphere during the experiments was $3.0 \% \mathrm{CO}_{2}, 18 \% \mathrm{O}_{2}, 74 \% \mathrm{~N}_{2}$ and $5 \%$ $\mathrm{H}_{2} \mathrm{O}$ with an average gas flow of $12.7 \mathrm{Nm}^{3} \cdot \mathrm{h}^{-1} \mathrm{CH}_{4}$ and $19.0 \mathrm{Nm}^{3} \cdot \mathrm{h}^{-1} \mathrm{O}_{2}$.

According to the author [6] a further very harmful element, $\mathrm{Pb}$, is released in the form of $\mathrm{PbO}$ at temperatures above $850{ }^{\circ} \mathrm{C}$ without chlorination. When using $\mathrm{Cl}$, all the lead elements are captured in the form of $\mathrm{PbCl}_{2}$. If we increase the temperature to $1,000{ }^{\circ} \mathrm{C}$, it is possible to use only the heat to remove up to $100 \%$ of $\mathrm{Pb}$. The impact of temperature, the addition of $\mathrm{Cl}$ and other additives for the removal of undesirable elements were compiled by the author [6] in Table 1 .

Table 1 Relevant parameters influencing the removal of heavy metals from sewage sludge ash by chlorination [6]

\begin{tabular}{|c|c|c|c|c|c|c|c|c|c|}
\hline \multirow{2}{*}{$\begin{array}{l}\text { Heavy } \\
\text { metals }\end{array}$} & \multirow{2}{*}{ Temperature } & \multirow{2}{*}{$\begin{array}{c}\mathrm{Cl} \\
\text { addition }\end{array}$} & \multirow{2}{*}{$\begin{array}{c}\mathrm{Cl} \\
\text { availability. }\end{array}$} & \multicolumn{4}{|c|}{$\begin{array}{c}\text { Major elements in the } \\
\text { ash }\end{array}$} & \multicolumn{2}{|c|}{ Gas composition } \\
\hline & & & & Al & $\mathrm{Ca}$ & $\mathrm{Fe}$ & Si & $\mathrm{H}_{2} \mathrm{O}$ & $\mathrm{O}_{2}$ \\
\hline $\mathrm{Cd}$ & + & 0 & 0 & 0 & $(+)$ & 0 & - & ++ & 0 \\
\hline $\mathrm{Cr}$ & + & ++ & ++ & 0 & $(-)$ & 0 & ++ & -- & ++ \\
\hline $\mathrm{Cu}$ & ++ & + & + & $(+)$ & 0 & - & ++ & 0 & 0 \\
\hline $\mathrm{Ni}$ & ++ & ++ & ++ & 0 & 0 & - & $(-)$ & -- & $(-)$ \\
\hline $\mathrm{Pb}$ & + & $(+)$ & 0 & 0 & + & 0 & + & 0 & 0 \\
\hline $\mathrm{Zn}$ & ++ & ++ & ++ & $(-)$ & + & $(-)$ & + & -- & 0 \\
\hline
\end{tabular}

++ strongly positive influence; + positive influence; $(+)$ low positive influence; 0 no influence; (-) low negative influence; - negative influence; -- strongly negative influence.

\section{RESEARCH LABORATORY IN MMV}

In connection with the known and available processes taking place in the rotary kiln, the design of the research equipment (rotary kiln) is being done at the company MATERIÁLOVÝ A METALURGICKÝ VÝZKUM s.r.o. (MMV). The fired rotary kiln is highly demanding as regards control of the temperature in the kiln, flue gas content, kiln size, response options (oxidation and reduction) and mainly the attachments such as preparation of the heating gas, cleaning of flue gases, suction, etc. From the viewpoint of control, monitoring and precise evaluation, it is more suitable to have a rotary kiln with an electric heat source. For such a kiln, it is possible to very precisely regulate the heat in the kiln, control the composition of the input gases used in the process as well as evaluate and monitor the composition of the output gases and their contents.

Assumed parameters of the rotary kiln:

- $\quad$ Rotary kiln, drum kiln working in the temperature range of 100 to $1,600{ }^{\circ} \mathrm{C}$.

- Indirect electric heating using a spiral heating element, heating rate $500^{\circ} \mathrm{C}$. hour ${ }^{-1}$, possibility to control the temperature with a precision of $1^{\circ} \mathrm{C}$.

- $\quad$ Optional circumferential rotation speed from 5 to $314 \mathrm{~mm} \cdot \mathrm{s}^{-1}$, rotation period from 1 to $61 \mathrm{r}$.s $\mathrm{s}^{-1}$.

- The controlled input temperature in the kiln assumes the use of the gaseous elements $\mathrm{O}_{2}, \mathrm{Cl}$ (or $\mathrm{CaCl}_{2}$ ), $\mathrm{CO}_{2}, \mathrm{NOx}, \mathrm{SOx}, \mathrm{N}_{2}, \mathrm{Ar}, \mathrm{CH}_{4}$ (methane), $\mathrm{C}_{3} \mathrm{H}_{8}$ (propane), $\mathrm{C}_{4} \mathrm{H}_{10}$ (butane), $\mathrm{H}_{2} \mathrm{O}, \mathrm{CO}$. 
- The volume of gaseous mixture, temperature, pressure and gaseous composition is measured at the kiln inlet and outlet.

- $\quad$ The samples shall be in granular or powder form with a total weight of up to $0.5 \mathrm{~kg}$.

\section{CONCLUSION}

The work represents partial project tasks that focused on research into the methods of management of wastes, materials and by-products from metallurgical and related plants. Based on negotiations with the project cosolver, the research areas were preliminarily identified. They mainly include the issue of removal of $\mathrm{Zn}$ from metallurgical wastes. Within the framework of this project, MATERIÁLOVÝ A METALURGICKÝ VÝZKUM s.r.o. is currently designing a research laboratory with a rotary kiln to be used for the elimination of harmful admixtures of $\mathrm{Zn}$ from metallurgical wastes.

\section{ACKNOWLEDGEMENTS}

This project is co-funded by the European Regional Development Fund within the scope of the Operational Programme Research, Development and Education under the patronage of the Ministry of Education, Youth and Sport, project reg. number CZ.02.1.01/0.0/0.0/17_049/0008426

\section{REFERENCES}

[1] FEECO International [online]. Rotary dryer. Handbook @ 2018. [viewed 2019-05-10]. Available from: https://feeco.com/rotary-dryers/

[2] PICHLER, C., ANTREKOWITSCH, J. Pyrolysis Gas as a Renewable Reducing Agent for the Recycling of Zincand Lead-Bearing Residues: A Status Report. [online]. 2017. vol. 69, pp. 999-1006 [viewed 2019-05-10]. Available from: https://link.springer.com/article/10.1007/s11837-017-2341-7. DOI: 10.5530/rjps.2012.2.1.

[3] WILLIAMSON IR [online]. Temperature Control of Flame Fired Processes. Handbook @ 2018. [viewed 2019-0510]. Available from: https://www.williamsonir.com/blog/temperature-control-of-flame-fired-processes/.

[4] NSI Equipments Private Limited [online]. Calcination Rotary Kilns Manufacturers. [viewed 2019-05-10]. Available from: http://www.nsiequipment.com/rotary-kilns.html\#bas.

[5] HARALD, J., ENGELSEN, J., SINTEF, E. Building and Infrastructure Water and Environment [online]. Environmentaly Sound Management of Hazardous and Industrial Wastes in Cement Kilns - Waste as Alternative Raw Materials. [viewed 2019-05-10]. Available from: https://sintef.brage.unit.no/sintefxmlui/bitstream/handle/11250/2406469/SBFINA0733.pdf?sequence=3.

[6] FRAISSLER, G., JÖLLER, M., MATTENBERGER, H., BRUNNER, T., OBERNBERGER, I. Thermodynamic equilibrium calculations concerning the removal of heavy metals from sewage sludge ash by chlorination. [online]. 2008. pp. 1-13. Available from: https://www.bioenergy2020.eu/files/publications/pdf/l2-429.pdf. DOI: 10.1016/j.cep.2008.03.009 